\title{
Relationship Between Knowledge of Hand Washing Soap with Hand Washes Attitude in Students of SMP Dumoga 9
}

\author{
Febi Kornela Kolibu ${ }^{1 *}$, Maureen Irenne Punuh ${ }^{1}$
}

\author{
${ }^{1}$ Public Health Faculty, Sam Ratulangi University, Indonesia \\ "Corresponding author. Email: febikolibu@unsrat.ac.id
}

\begin{abstract}
Hand washing soap is one of the sanitary measures taken to remove germs and bacteria that adhere to the hands. Nowadays, there are still many Indonesian children who die from diarrhea. According to the Family Health Director of the Indonesian Ministry of Health, every year as many as 1.7 million children die from diarrhea. In Bolaang Mongondow district, the number of diarrhea cases was 299 cases and was ranked second out of 10 prominent diseases in Bolaang Mongondow District. The purpose of this study was to determine the relationship between knowledge of hand washing soap with hand washing attitude in students of SMP Negeri 9 Dumoga, Bolaang Mongondow District. This research is an analytic survey research with cross sectional study. The population is students on grade IX, the sample is the total population of 41 students. Data were analyzed with descriptive analysis and correlation using the Chi Square Test. Most respondents had good knowledge (78\%) on washing hands with soap and most respondents $(95.1 \%)$ had a good attitude about washing hands with soap. There is a relationship between students' knowledge about washing hands with soap with students' attitudes about washing hands with soap with $\mathrm{p}$ value of $0.005(<0.05)$. There is a relationship between between knowledge of hand washing soap with hand washing attitude in students of SMP Negeri 9 Dumoga.
\end{abstract}

Keywords: knowledge, attitude, hand washing soap

\section{INTRODUCTION}

Washing hands with soap is one of the sanitary measures by cleaning the hands and fingers using water and soap to break the chain of germs and effort to prevent disease. Washing hands with soap is an effort to prevent disease, because hands are often carry germs and cause pathogens that move from one person to another, either by direct or indirect contact, namely through towels, glasses and other surfaces [5]. Hand washing is one of the most effective ways to prevent disease and has a good impact on people's health.Washing hands with soap can prevent diarrhea, acute respiratory infections and influenza becauseit can prevent transmission from various infections [1]. Washing hands can kill germs and eliminate chemicals in the hands. But if soap and water are not available, using a hand sanitizer with at least $60 \%$ alcohol can help to prevent disease and spread germs to others (CDC).

Diarrheal disease is one of the leading causes of child death worldwide.World Health Organization (WHO) estimates that every year, there are more than 2.2 million people who die from diarrhea so it is recommended that hand washing be done substantially to reduce the risk of diarrhea(Burton, dkk). Until now, there are still many Indonesian children who die from diarrhea. According to the Family Health Director of the Indonesian Ministry of
Health, every year as many as 1.7 million children die from diarrhea [11]. According to Riskesdas 2013, Diarrhea is the number one cause of death in infants (31.4\%) and in toddler $(25.2 \%)$, whiles in all age groups the number four cause of death $(13.2 \%)$. The number of cases of diarrhea and gastroenteritis caused by infection in BolaangMongondow Regency in 2016 amounted to 299 cases and ranked second out of 10 prominent diseases in BolaangMongondowRegency [13]. In a study of factors related to the occurrence of diarrhea in children under five in Bintauna Health Center, North BolaangMongondow district, it was found that the hygiene factor is one of the factors associated with the occurrence of diarrhea.

Knowledge and attitude are important factors that affect one's health, especially in washing hands with soap to prevent diarrhea.Knowledge is the result of knowing and occurs after people sensing certain objects through sensing both through sight, hearing, smell, taste, and touch [7]. Attitude is a person's closed response to a particular stimulus or object.For example those that have involved the opinion and emotion factors that are relevant or happy and unhappy, agree and disagree, good and not good [8]. Based on the description above, this research was conducted with the aim to find out the description of knowledge and attitude of washing hands with soap in the students of SMP Negeri 9 Dumoga also knowing the relationship between knowledge and attitude of washing hands with soap in students of SMP Negeri 9 Dumoga.The 
soap, hands must be dried using a clean cloth or tissue.The results of this study are in line with research conducted by Murwanto [6] in research on behavioral factors of washing hands with soap. The results show that most junior high school students (80\%) have good knowledge about washing hands with soap as well as research conducted by Risnawaty [12] about the determinants of hand washing with soap obtained results $74.3 \%$ have good knowledge about washing hands with soap.From interviews with several students, information was obtained that they got information about washing hands with soap from electronic media. Notoatmodjo (2014) [9] suggests that behavior based on knowledge will last longer than behavior that is not based on knowledge.

\section{Respondents'Attitudes About Handwashing with Soap}

The results of a study conducted at Dumoga 9 Junior High School found 95.1 students to have a good or positive attitude about washing money using soap. Positive attitude is supported by the statement of students stating that washing hands is important, before eating sister is required to wash hands with soap, we must wash hands after defecation and when washing hands palms and between fingers need to be rubbed with soap and rinsed with water flow.The results of this study are supported by research conducted by Halim and Sudirman (2018)[4] with qualitative methods with the results obtained by all informants being positive about CPTS behavior, they feel that washing hands can clean their hands from germs so they can help maintain health.The results of this study are also in line with research conducted by Risnawati (2016)[12]. The results of 92.9 respondents have the attitude of supporting hand washing with soap.

\section{The Relationship Between Knowledge of Handwashing with Soap with Attitude to Washing Hands with Soap}

The results of the bivariate analysis showed that there was a relationship between knowledge with handwashing with soap where the $\mathrm{p}$ value obtained was $0.005<\alpha(0.05)$ with a strong positive correlation coefficient which showed that increasing student knowledge would be accompanied by increased student attitudes and vice versa.

\section{CONCLUSION}

1. Most students of Dumoga 9 Junior High School have good knowledge and attitudes about washing hands with soap.

2. There is a relationship between the knowledge of washing hands with soap with the attitude of washing hands with soap in students at SMP Negeri 9 Dumoga. 


\section{SUGGESTION}

1. Counseling about hand washing with soap is needed for students of SMP Negeri 9 Dumoga both by the school and by the Puskesmas and the local health office.

2. The need to provide facilities in schools to support the program of washing hands with soap.

\section{REFERENCES}

[1] Burton M, Cobb E, Donachie P, Judah G, Valcurtis, Cchmidt WP. 2018. "The Effect Of hand washing with water or soap on bacterial contamination of hands". International journal Of Environment Research and public health 8 .

[2] Center Of Disease Control And Prevention (CDC). "Show me the science when and how to use hand sanitizer in community settings" https://www.cdc.gov/handwashing/show-me-the-sciencehand-sanitizer.html

[3] Departemen Kesehatan RI. 2013.Riset Kesehatan Dasar. Jakarta

[4] Halim, Soedirman. 2018. Perilaku Cuci Tangan Di Kalangan siswa siswi SMAK Santa Agnes surabaya. The Indonesian Journal Of Public Health Vol 13 N0 2.

[5] Kementerian Kesehatan Republik Indonesia Pusat data dan Informasi, 2014. "Perilaku Mencuci Tangan Pakai sabun Di Indonesia".

\section{[6] Murwanto B, 2017. Faktor Perilaku Cuci Tangan Pakai Sabun (CTPS) di SMP.JurnalKesehatan, Volume VIII, Nomor 2, Agustus 2017, hlm 269-276}

[7] Notoadmodjo 2007. "Promosi Kesehatan dan Ilmu Perilaku”. Rineka Cipta. Jakarta

[8] Notoadmodjo 2010. “ Metodologi Penelitian kesehatan. Rineka Cipta. Jakarta.

[9] Notoatmodjo. (2014). Ilmu Perilaku

[10] Kesehatan. Jakarta: PT.Rineka Cipta

[11] Pentingnya Cuci Tangan pakai sabun https://www.motherandbaby.co.id/article/2017/11/11/8790/ Pentingnya-Cuci-Tangan-Pakai-Sabun diakses 28 Februari 2019

[12] Risnawaty. 2016. Fakor Derminan Perilaku Cuci Tangan Pakai Sabun (CTPS) Pada Masyarakat Di tanah Kalikendinding. Jurnal Promkes Vol 4 No 1.

[13] Tangka J, Alamri R, Laoh JM, 2014. Faktor-faktor Yang Berhubungan Dengan Kejadian Diare pada Anak Balita Di Puskesmas Bintauna Kabupaten Bolaang Mongondow Utara. JUIPERDO, VOL 3, N0. 2 September2014 